\title{
GROUP INSURANCE POLICIES: THE EMPLOYER/INSURER AGENCY RELATIONSHIP
}

7 THE SIGNIFICANT increase in issuance of group insurance contracts in the past twenty years has estabhished this type of coverage as an important coinponent of employee fringe benefits. ${ }^{1}$ Employers have found that group insurance, providing low cost protection to employees, generally without a medical examination, can increase employee loyalty and reduce labor turnover. Mass policy solicitations and renewals benefit the insurer through reduced administrative costs, passed on in large part to the insured group through lower premium rates. ${ }^{2}$ Precursory group insurance plans maintained the traditional contractual relationship between the insurance company and the employee, allowing the employer to perform only minimal clerical duties. Today, the pressures of competition and rising costs lave produced frequent delegation of administrative detail by the insurer to the employer; and often the insurer has little contact with the insured employee. ${ }^{3}$ This trend has advanced to the point that in some cases the "insurer does little more than lend its name to the program," accepting premiuns and paying claims determined by the employer, who is subject to an occasional cursory audit. Typically, the master pohcy is issued in the name of the employer, and individual "certificates" of insurance are subsequently distributed to qualifying employees. Premiums are commonly paid from joint employer contribution and employee wage deductions. Eligibility for insurance, and even for claim benefits, is often determined by the employer-master policy holder. With the employer carrying out many of the administrative duties traditionally performed by the insurance company, the extent to which an employer's acts will bind the insurer has becoine of significant concern.

If the employer acts as the agent of the insurer, the insurance company will be bound by the employer's administrative mistakes. ${ }^{5}$ The im-

${ }^{1}$ In 1966 Group coverage amounted to more than $\$ 300$ billion, equalling $35 \%$ of all life insurance in force; $85 \%$ of all group policies were of the employer/employee type. INSTTTUTE of LIFE INSURANCE, LIFE INSURANCE FACT BooK 26-27 (1966).

2 See D. GREGG, Group LIFE INSURANCE 9-11 (1957).

${ }^{3}$ B. Swank, The Group Policyholder-Agent for Insurance Company or for Persons Insured, P.4, October 12, 1965 (unpublished paper on file with the Duke Law Journal).

'Id. at 4-5.

${ }^{5}$ See Piedmont Southern Life Ins. Co. v. Gunther, $108 \mathrm{Ga}$. App. 236, 238, 132 S.E.2d 527, 530 (1963); Baum v. Massachusetts Mut. Life Ins. Co., 357 P.2d 960, 
portance of this agency determination is well illustrated in the recent California Supreme Court case of Elfstrom v. New York Life Insurance Company. ${ }^{3}$ Elfstrom, president and majority stockholder of the Fullerton Publishing Company, instructed his bookkeeper to secure company group insurance for his daughter, a part-time employee of the firm. During an ensuing prolonged absence of her employer, the bookkecper, knowing that the daughter's status was inadequate for coverage under the master pohicy, completed a pre-signed application form requesting $\$ 4,000$ coverage, and issued an insurance certificate with Elfstrom as beneficiary. In accordance with established procedure, the apphication forms were retamed at the Fullerton headquarters with other group policy records. Following the daughter's death some six months after the company began premium payments on the policy addition, the insurer refused to pay the policy benefits, contending that Miss Elfstrom had been meligible for insurance coverage under the terms of Fullerton's group policy. Asserting that the bookkeeper had acted as the agent of the insurance company, Elfstrom, as beneficiary, sued to recover the proceeds of the pohicy. New York Life Insurance Company demied existence of an agency relationship, and filed a cross complaint for recision of the insurance certificate on the grounds that Elfstrom liad concealed material facts. ${ }^{7}$ The trial and appeals courts found that the bookkeeper, in procuring insurance for Elfstrom's daughter, was acting as her agent and held for the insurer on the complaint and cross complaint. ${ }^{8}$ The California Supreme Court unanimously reversed, holding that an employer acts as the agent of the insurer in performing functions necessary to administer group insurance, 9 but remanded the case for determination of the unanswered issue of Elfstrom's intent.

Although most court decisions in the area of group insurance have been limited to an examination of one or two aspects of the agency relationship, there are sufficient state court cases to formulate the traditional pattern of majority and minority positions. The majority view, that the employer is agent of his employees, ${ }^{10}$ assumes that the employer

964 (Okla. 1960). See also F. MECHEM, LAW of AgENCY, §§ 129, 138 (1952); Restatement (SecoNd) of AgeNCY §§ 154, 282(2) (1958).

-Cal. 2d—, 432 P.2d 731, 63 Cal. Rptr. 35 (1967).

'Id. at—, 432 P.2d at 734, 63 Cal. Rptr. at 38.

${ }^{8}$ Elfstrom v. New York Life Ins. Co., $\longrightarrow$ Cal. App.2d —,, 56 Cal. Rptr. 601, 604 (Ct. App. 1967).

- Cal. 2d at—, 432 P.2d at 737, 63 Cal. Rptr. at 41.

${ }^{10}$ See Boseman v. Connecticut General Life Ins. Co., 301 U.S. 196 (1937); Metropolitan Life Ins. Co. v. Quilty, 92 F.2d 829 (7th Cir. 1937); Metropolitan Life 
does not enter the insurance contract for the benefit of the insurance company; rather, he is motivated by a paternalistic desire to benefit his employees ${ }^{11}$ or by desire to strengthen his business through better labor relations. ${ }^{12}$ In administering the group pohicy the employer functions as the representative of his employees; thus, the interests of the employer and employee are aligned and adverse to that of the insurer. ${ }^{13}$ Finally, it has been argued that because the insurer and employer are the contracting parties, with the employer naned as the policy holder, the employer cannot logically function as the agent of the insuring company. ${ }^{14}$ The minority view, finding an employer/insurer agency relationship, ${ }^{15}$ focuses upon the employer's performance of the traditional insurer administrative functions, and emphasizes the employee's lack of knowledge of and

Ins. Co. v. Thompson, 203 Ark. 1103, 160 S.W. 2d 852 (1942); Morales v. Equitable Life Assurance Soc'y, 115 Ind. App. 565, 60 N.E.2d 747 (1945); Continental Assurance Co. v. Henson, 297 Ky. 764, 181 S.W.2d 431 (Ct. App. 1944); Wing v. John Hancock Mut. Life Ins. Co., 314 Mass. 269, 49 N.E.2d 905 (1943); Satz v. Prudential Ins. Co., 225 S.W.2d 480 (Mo. Ct. App. 1947); Duval v. Metropolitan Life Ins. Co., 82 N.H. 543, 136 A. 400 (1927); Keane v. Aetna Life Ins. Co., 22 N.J. Super. 296, 91 A.2d 875 (1952); Fidelity and Cas. Co. v. Metropolitan Life Ins. Co., 42 Misc. 2d 616, 248 N.Y.S.2d 559 (Sup. Ct. 1963); Boger v. Prudential Ins. Co., 259 N.C. 125, 130 S.E.2d 64 (1963); Layman v. Continental Assurance Co., 416 Pa. 155, 205 A.2d 93 (1964); Ralston v. Metropolitan Life Ins. Co., 90 Utah 496, 62 P.2d 1119 (1936). But see Clauson v. Prudential Ins. Co., 195 F. Supp. 72 (D. Mass), aff'd, 296 F.2d 76 (1st Cir. 1961); Patterson v. John Hancock Mut. Life Ins. Co., 27 IIl. App. 2d 135, 169 N.E.2d 183 (1960); Carter v. Aetna Life Ins. Co., 272 Ky. 392, 114 S.W.2d 496 (Ct. App. 1938).

II See Duval v. Metropolitan Life Ins. Co., 82 N.H. 543, 550, 136 A. 400, 404 (1927). But see Shears v. All State Life Ins. Co., 242 Ala. 249, 253, 5 So. 2d 808, 811 (1942).

${ }^{13}$ See Hroblak v. Metropolitan Life Ins. Co., 50 Ohio L. Abs. 395, 403, 79 N.E.2d 360, 364 (Ct. App. 1947).

${ }^{23}$ See Duval v. Metropolitan Life Ins. Co., 82 N.H. 543, 550, 136 A. 400, 404 (1927); Fidelity \& Cas. Co. v. Metropolitan Life Ins. Co., 42 Misc. 2d 616, 631, 248 N.Y.S.2d 559, 572 (Sup. Ct. 1963).

${ }^{14}$ See, e.g., Elfstrom v. New York Life Ins. Co., —-Cal. 2d-, - 432 P.2d 731, 738, 63 Cal. Rptr. 35, 42 (1967).

${ }^{15}$ See Provident Life \& Accident Ins. Co. v. Dotson, 93 F. Supp. 538 (S.D.W. Va. 1950); Piedmont Southern Life Ins. Co. v. Gunter, 108 Ga. App. 236, 132 S.E.2d 527 (1963); Rhodes v. Rhodes, 251 Iowa 430, 101 N.W.2d 1 (1960); Exstrum v. Umion Cas. \& Life Ins. Co., 165 Neb. 554, 86 N.W.2d 568 (1957), affd on rehearing, 167 Neb. 150, 91 N.W.2d 632 (1958); Baum v. Massachusetts Mut. Life Ins. Co., 357 P.2d 960 (Okla. 1960); Coker v. Aetna Life Ins. Co., 188 S.C. 472, 199 S.E. 694 (1938); Vulcan Life and Accident Ins. Co. v. Segars, 6 Life Cas. 2d 851 (Tenn. 1965); General American Life Ins. Co. v. Gant, 119 S.W.2d 693 (Tex. Civ. App. 1938); Kaiser v. Prudential Ins. Co., 272 Wis. 527, 76 N.W.2d 311 (1956). But see Prude v. Equitable Life Assurance Soc'y, 113 F. Supp. 215, 216 (S.D.W. Va. 1952); Boyd v. Travelers Ins. Co., 421 S.W.2d 929 (Tex. Civ. App. 1967). 
control over the actions of his employer. ${ }^{10}$ A number of states have statutes that affix the agency label on parties conducting various aspects of the imsurer's busimess, ${ }^{17}$ and courts occasionally have found these enactments determinative in the group imsurance context. ${ }^{18}$ No state has undertaken a pervasive regulation of the problem, ${ }^{19}$ nor have imsurers attempted to settle the conflict by policy provision. ${ }^{20}$

Faced with the necessity of resolving the divergent positions taken by courts applying California law to the agency question, ${ }^{21}$ the California Supreme Court, in Elfstrom, noted that the employer administering a group plan acts both in furtherance of his interests and for the benefit of his employees. ${ }^{22}$ Since the employees, in the court's view, were the real parties-in-interest, with all the incidents of ownership usually associated with a life insurance policy, the court rejected the argument that by naming the employer beneficiary of the master policy an agency relationship was made conceptually impossible. Adjudging the issue of control to be determinative of the agency question, the California court concluded that employees have neither effective knowledge of, nor control over employer administration of a group insurance plan. The insurer, on the other hand, directs the actions of the employer and lias the power to exercise effective administrative control; thus, in administering a group policy the employer acts as agent for the insurer, ${ }^{23}$ who will be bound by the employer's acts.

The imposition of the agency burden upon the insurance industry may, as the Elfstrom court has indicated, ${ }^{24}$ precipitate additional costs

${ }^{10}$ E.g., Clauson v. Prudential Ins. Co., 195 F. Supp. 72 (D. Mass.), aff d, 296 F.2d 76 (1st Cir. 1961); Neider v. Coutinental Assurance Co., 213 La. 621, 35 So. 2d 237 (1948).

${ }^{17}$ See, e.g., GA. CODE ANN. $\$ 56-8016$ (1960) (one who solicits policyholder is agent of insurer); OrLa. Stat. ANN. tit. 36, § 1302 (1958) (same); Tex. INs. Code art. 21.02 (1963) (receiver or collector of premiums is deemed agent of insurer).

${ }^{13}$ E.g., Provident Life \& Accident Ins. Co. v. Dotson, 93 F. Supp. 538, 540 (S.D.W. Va. 1950); Connecticut Gen. Life Ins. Co. v. Speer, 185 Ark. 615, 618, 48 S.W.2d 553, 554 (1932); Equitable Life Assurance Soc'y v. Hall, 253 Ky. 450, 452, 69 S.W.2d 977, 978 (1934); General Am. Life Ins. Co. v. Gant, 119 S.W.2d 693, 695 (Tex. Civ. App. 1938).

${ }^{10}$ But see Mrch. Stat. ANN. \$ 24.14416 (1960) (financial institution, as group creditor, shall not act as agent for insurer).

${ }^{\circledR}$ But see note 27 infra and accoinpanying text.

II John Hancock Mut. Life Ins. Co. v. Dorman, 108 F.2d 220 (9th Cir. 1939); Eason v Aetna Life Ins. Co., 212 Cal. App. 2d 607, 28 Cal. Rptr. 291 (1963).

${ }_{23}-\mathrm{Cal} .2 \mathrm{~d}$ at-, 432 P.2d at 737, $63 \mathrm{Cal}$. Rptr. at 41 (1967).

${ }^{23} \mathrm{Id}$. at—, 432 P.2d at 737, $63 \mathrm{Cal}$. Rptr. at 41.

$\approx$ Id. at-, 432 P.2d at 738,63 Cal. Rptr. at 42. 
and higher premiums. Yet, continued functioning of group insurance plans in states adopting the minority rule tends to show that this burden is not econoinically destructive. Further, because it focuses upon capacity to prevent future errors and abuses, rather than upon alignments of interests and motivational factors, as docs the inajority rationale, the ininority approach has been viewed as the more equitable. ${ }^{25}$ Another analysis which inay be useful to the courts would result from an investigation of the nature of the particular administrative task involved. The degree of discretionary delegation involved, the scope of possible insurer control, and the adversary posture of the employer toward the imsurer when undertaking a particular task may be relevant factors in assessing the relationship connate to the undertaking. Thus, delegated clerical duties, such as receipt and forwarding of applications, recording of beneficiaries, and collecting of premiums, would imply an insurer/enployer agency relationship because they are susceptible to a high degree of control and align the interests of employer, einployees, and insurance coinpany. On the other hand, discretionary duties such as determination of claims; termination of policies; dissemination of information concerning policy provisions, einployment status, and premium payments; or waiver of policy provisions, may not imply agency. Although the insulating effect of policy provisions relating to the agency question has been definitively treated, ${ }^{20}$ the insurer might nonetheless minimize the agency threat by establishing procedures designed to confirm the employer's position as representative of lis employees. Appropriate contract provisions might encompass such matters as reserving to the insurer determination of employee eligibility and requiring regular audits of the employer's records and procedures. ${ }^{27}$ Yet, irrespective of attempts by the insurer to avoid the agency relationship, it appears that the present trend toward self-accounting and selfadministered group insurance policies portends contmued close scrutiny of the employer/insurer relationship.

201 J. Appleman, Insurance Law and Practice 55 (1965).

${ }^{26}$ See Blue Cross-Blue Shield v. Fowler, 43 Ala. App. 572, 580, 195 So. $2 d 910$, 918 (1966), cert. denied, 280 Ala. 708, 195 So. 2d 919 (1967).

${ }^{2 \pi}$ B. Swank, supra note 3 , at 51-53. 